\title{
Genomic variability in Vitis vinifera L. "Sangiovese" assessed by microsatellite and non-radioactive AFLP test
}

\author{
Vignani Rita * \\ Dipartimento di Scienze Ambientali \\ Via P.A. Mattioli 4, Università degli Studi di Siena \\ 53100 Siena, Italia \\ Tel: 39-0577-232856; 39-0577-232910 \\ Fax: 39-0577-232860 \\ E-mail: vignani@unisi.it \\ Scali Monica \\ Dipartimento di Scienze Ambientali \\ Via P.A. Mattioli 4, Università degli Studi di Siena \\ 53100 Siena, Italia \\ Tel: 39-0577-232856; 39-0577-232910 \\ Fax: 39-0577-232860 \\ E-mail: scalimoni@unisi.it \\ Masi Elisa \\ Dipartimento di Ortoflorofrutticultura \\ Via Doninzetti 6, Università degli Studi di Firenze \\ 50144 Firenze, Italia \\ Tel: 39-0577-333463 \\ Fax: 39-0577-331497 \\ E-mail: elisa.masi@unifi.it \\ Cresti Mauro \\ Dipartimento di Scienze Ambientali \\ Via P.A. Mattioli 4, Università degli Studi di Siena \\ 53100 Siena, Italia \\ Tel: 39-0577-232854; 39-0577-232910 \\ Fax: 39-0577-232860 \\ E-mail: cresti@unisi.it
}

Financial support: The present work has been done in the framework of a research programme (1997-2001) developed in the area of viticulture and wine making funded by the Tuscan regional authority ARSIA (Agenzia Regionale per lo Sviluppo e l'Innovazione nel Settore Agricolo-Forestale).

Keywords: clone variation, polymerase chain reaction, sequence tagged sites, variety identification.

Abbreviations: PCR, polymerase chain reaction; AFLP, amplified fragment length polymorphism; $\mathrm{Cy} 5, \mathrm{Cy}^{\mathrm{TM}} 5$ amidite (5'-cyamine-d[seq]) fluorochrome technology.

Microsatellite polymorphism analysis on 25 different "Sangiovese" accessions was carried out at eight microsatellite loci (VVS2, VVS4, VVS29, VVMD3, VVMD6, VVMD7, VVMD17 and VVMD21). In order to evaluate variability within the "Sangiovese" variety and to confirm variety identification, genotype analysis, allele distribution and pedigree information were processed with a DNA-automated sequencer running AlleleLinks software.

DNA typing revealed three cases of genetic dissimilarity compared to registered "Sangiovese" clones and the divergent accessions thought to be different clones of the same variety. The divergent accessions were different from "Sangiovese" at four microsatellite loci (VVS2, VVS4, VVMD7 and VVMD21). An innovative non- radioactive modification of AFLP genome profiling confirmed the data obtained by microsatellite amplification test. These results underline the importance of biotechnological testing, such as the PCRbased DNA tests together with traditional ampelography, in Vitis vinifera $\mathrm{L}$. clone and variety selection programmes to avoid misnaming and erroneous identification and to evaluate genetic relatedness and variability within populations.

Many famous wines derived from Vitis vinifera L cultivars, typically grown in different areas of Tuscany, have been highly regarded for centuries. Like most fine wines and traditional products, they are made essentially from old cultivars such as "Sangiovese", "Trebbiano toscano",

* Corresponding author 
"Malvasia", and colour releasing scions called locally "Colorino".

Grapevines are propagated by cuttings and the resulting clones of a given population are genetically identical to each other (except for somatic mutations) and to the mother plant (the original seedling from which cultivars were derived). The long history of grapevine growth has determined a complex picture in which many biotypes or even cultivars are misidentified or called by different names in different areas. This often makes genetic identification difficult. In addition, the origin of most cultivars is unknown and the biological framework behind the complex variability of $V$. vinifera is complicated by many factors, including spontaneous crossing events which might have occurred during the species' domestication.

Loss of biodiversity in the grapevine is largely due to the past tendency of applying strong genetic and selective pressures to this crop, resulting in the loss of so-called "minor" clones or biotypes in many Italian regions (Scienza, 1993; Silvestroni et al. 1997; Fregoni, 1999).

Thus it seems evident that any scientific programme aimed at increasing plant quality or preserving the integrity of the genetic resources of this species must consider the problem of plant identification at variety or clone level. The high degree of polymorphism characterising microsatellites has made them useful markers for studying genetic diversity among quasi-isogenic populations (Morgante and Olivieri, 1993).

The microsatellite amplification test is mainly used to verify genetic identity, to facilitate management of the cultivar collections and recently to determine the geographic origin of cultivars (Sefc et al. 1998; Sefc et al. 2000).

The usefulness of molecular testing for grapevine identification is largely documented in recent literature (Thomas and Scott, 1993; Cipriani et al. 1994; Thomas et al. 1994; Bowers et al. 1996; Bowers and Meredith, 1997). Combining microsatellite amplification testing with appropriate statistical analysis has enabled the ancestry of modern varieties to be traced (Bowers et al, 1999; Dettweiler et al. 2000). Microsatellite technology has also been extensively used in grapevine biology and genetics. The number of loci available has greatly increased in the last three years largely through the establishment of the international Vitis Microsatellite Consortium (VMC), coordinated by Agrogene (www.agronene.com) in France, which has led to the discovery of more than 350 new loci (Isaac, personal communication). Nevertheless, the information deriving from its application on limited numbers of individuals needs improvement. The use of multiple PCR-based markers helps to overcome some of the intrinsic limits of the microsatellite amplification test in Vitis vinifera populations, such as the partial or nonstandard information on alleles size and frequencies. In addition, the use of multiple DNA tests is in keeping with the terms of the recent international Vitis genome project (http://www.genome.clemson.edu/projects/stc/grape/VV_S $\mathrm{Ba})$.

AFLPs (Vos et al. 1995) enable complete PCR-based description of the entire genome which can complement the more focused allele-based description of the microsatellite amplification test. In the present study, we employed a technical variant of the classical AFLP test with non radioactive labelling.

Our aim was to demonstrate the utility of PCR-based DNA markers in Vitis vinifera for distinguishing accessions which diverge from a certain variety and for defining the phylogenetic relationship of unknown individuals of this species.

\section{Materials and Methods}

\section{Plant Material}

Twenty-five grapevine accessions believed to belong to "Sangiovese" variety grown in different areas of Tuscany were analysed at eight microsatellite loci. The grapevines analysed and the "Sangiovese" clones used as positive controls for allelic size determination are listed in Table 1.

Plant material was kindly provided by Prof. G. Scalabrelli, University of Pisa (www.unipi.it) and by Prof. M. Boselli, University of Florence (www.unifi.it). Several plants, including "Sangiovese" clones used as standards (SS-F9A5-48, BB-S-11, VCR-10) were from germoplasm collection vineyards and are available commercially; BD1 and BD2 were from the Montalcino area, kindly provided by Prof. Pisani, University of Florence. The other accessions are grown in different parts of Tuscany, for example "Sangiovese" from the area of Scansano, Grosseto, (CH, LA, ROSSI3 and GA series), known for the DOC wine Morellino, and presumed clones of "Sangiovese" grown in the area of Val di Cornia (accessions labelled COR) under the 5-year (1997-2001) research breeding programme ("Miglioramento genetico delle produzioni vitivinicole e del materiale di propagazione" funded by ARSIA-Agenzia Regionale per lo Sviluppo e l'Innovazione nel Settore Agricolo forestale- the research promoting agency of the Tuscan Region).

\section{DNA preparation and quantification}

Total DNA was extracted from young leaves by a modification of the method reported by Mulcahy et al. (1993). DNA was further purified by elution through a 
Chroma-spin 1000 column (Clontech Laboratories, Inc. Palo Alto California, USA) (www.clontech.com) as described by Silvestroni et al. (1997). DNA integrity was qualitatively evaluated on standard agarose gels stained with ethidium bromide. DNA quantitation was obtained by comparison of $\mathrm{H} 33258$ dye incorporation detected with a Hoefer DyNA Quant ${ }^{\circledR} 200$ fluorometer (Amersham Pharmacia Biotech, Milano, Italy) (www.apbiotech.com) following the standard protocol and visual evaluation of ethidium bromide incorporation of unknown samples against uncut lambda DNA, used as standard on agarose gels. Genomic DNA was stored undiluted in TE $(10 \mathrm{mM}$ Tris, $1 \mathrm{mM}$ EDTA) buffer $\mathrm{pH} 8.0$ at $-20^{\circ} \mathrm{C}$.

\section{Microsatellite amplification conditions}

Eight microsatellite loci were analysed: VVS2, VVS4, and VVS29 were characterized by Thomas and Scott (1993); VVMD3 was isolated by Bowers et al. (1996); VVMD6, VVMD7, VVMD21, VVMD17 were isolated by Bowers and Meredith, (1997). Before PCR amplification each sample was diluted in water to a final concentration of 2.5 $\mathrm{ng} / \mu \mathrm{l}$ and kept at $4^{\circ} \mathrm{C}$. Amplification reaction was carried out with a total volume of $20 \mu \mathrm{l}$, obtained by adding $4 \mu \mathrm{l}$ of diluted DNA to $16 \mu$ l of reaction mixture. Each $16 \mu \mathrm{lmix}$ contained $2 \mu \mathrm{l} 10 \mathrm{X}$ Taq DNA buffer without $\mathrm{MgCl}_{2}$ (Promega) (www.promega.com), $1.6 \mu \mathrm{l}$ dNTP mix (2.5 $\mathrm{mM}$ each, Amersham Pharmacia Biotech), $0.8 \mu 1 \mathrm{MgCl}_{2}(25$ $\mathrm{mM}), 2 \mu \mathrm{l}$ each $5{ }^{\prime} \mathrm{Cy}^{\mathrm{TM}} 5$ amidite (5'-cyamine-d[seq]) fluorochrome labelled primer (both forward and reverse) and $0.1 \mu \mathrm{l}$ Taq DNA Polymerase (5 units/ $\mu$ l, Amersham Pharmacia Biotech).

Each reaction was overlaid with one drop of mineral oil (Sigma-Aldrich S.r.L, Milano Italy) (www.sigmaaldrich.com) and centrifuged at 16,000 $g$ for $30 \mathrm{sec}$.

A MJ PTC-200 DNA thermal cycler (M-Medical Genenco s.r.1. "Life Science", Firenze, Italy) (www.mmedical.it) was used, running a program consisting of one denaturation step ( 5 minutes at $94^{\circ} \mathrm{C}$ ) followed by 40 cycles of $(30 \mathrm{sec}$ at $92^{\circ} \mathrm{C} ; 30 \mathrm{sec}$ at annealing temperature calculated approximately as $-5^{\circ} \mathrm{C}$ less than theoretical annealing temperature on the basis of oligo primer sequence, and 1 min at $72^{\circ} \mathrm{C}$ ). A final elongation step at $72^{\circ} \mathrm{C}$ for 7 min was used at the end of the amplification process.

\section{Detection of microsatellite amplification products}

$\mathrm{Cy}^{\mathrm{TM}} 5$ amidite (5' -cyamine-d[seq]) fluorochrome labelled amplification products, (see above) were resolved on ReproGelTM High Resolution pre-made acrylamidebisacrylamide solutions $(8 \% \mathrm{w} / \mathrm{v})$ and detected on a semiautomated DNA sequencer, the ALFexpress II DNA Analysis System by Amersham Pharmacia Biotech. $2 \mu \mathrm{l}$ of amplification reaction were mixed with $3 \mu$ lof commercial denaturing loading solution (Amersham Pharmacia Biotech) and the whole volume was loaded on $0.1 \mathrm{~mm}$ thick gels after denaturing at $90^{\circ} \mathrm{C}$ for $2 \mathrm{~min}$ and immediate quenching on ice. The ladder used as internal standard was a mixture consisting of 100, 150, 200, 250 bp DNA fragments (AmershamPharmacia Biotech) diluted to a final concentration of 4 fentomoles each. The 50-500 bp ladder was used at a final concentration of 0.7 fentomoles and $5 \mu 1$ of this stock was loaded onto the gel.

Gels were run for $350 \mathrm{~min}$ at $600 \mathrm{~V}, 60 \mathrm{~mA}, 35 \mathrm{~W}$ and the temperature was maintained constant at $50^{\circ} \mathrm{C}$. Allele sizing, as well as genotyping and pre-linkage data on the studied population were performed by the use of AlleLinks software (Amersham Pharmacia Biotech).

\section{AFLP protocol}

For the AFLP analysis, a modification of the original method by Vos et al. 1995, was used. Major modifications included no radioactive use and primer labelling and significant changes were made in the PCR preamplification and amplification steps.

Genomic DNA was processed using the AFLP analysis System I-AFLP Starter Primer Kit (Gibco BRL Life Technologies) according to the manufacturer's instructions. The $\mathrm{Cy}^{\mathrm{TM}_{5}}$ amidite (5'-cyamine-d[seq]) fluorochrome labelled Eco RI primer was purchased by Amersham Pharmacia Biotech. The following primer combination was used:

\section{Eco RI: 5'-GACTGCGTACCAATTCACC-3';} MseI-CAA: 5' - GATGAGTCCTGAGTAACAA-3'

After partial digestion and ligation to adapters, DNA was amplified in two sequential steps called pre amplification and amplification. After dilution 10:1 in water, each sample underwent 20 cycles at $94^{\circ} \mathrm{C}$ for $30 \mathrm{sec}, 56^{\circ} \mathrm{C}$ for $1 \mathrm{~min}$ and $72^{\circ} \mathrm{C}$ for $1 \mathrm{~min}$ and either immediately processed for the following step or stored at $-20^{\circ} \mathrm{C}$. The amplification step consisted of 12 cycles at $94^{\circ} \mathrm{C}$ for $30 \mathrm{sec}, 65^{\circ} \mathrm{C}$ for $30 \mathrm{sec}$ (with a decreasing ramp of $0.7^{\circ} \mathrm{C}$ each cycle) and $72^{\circ} \mathrm{C}$ for 1 min followed by 23 cycles at $94^{\circ} \mathrm{C}$ for $30 \mathrm{sec}, 56^{\circ} \mathrm{C}$ for 30 sec and $72^{\circ} \mathrm{C}$ for $1 \mathrm{~min}$.

The AFLP products were resolved on denaturing polyacrylamide gels on an automated DNA sequencer (ALFexpress II, see above). Equal volumes of PCR products and standard denaturing loading buffer were mixed to a final volume of $6 \mu \mathrm{l}$. After denaturation at $92^{\circ} \mathrm{C}$ for $3 \mathrm{~min}$ and rapid quenching on ice for $2 \mathrm{~min}$, the whole sample was loaded on the gel. ReproGel ${ }^{\mathrm{TM}}$ High Resolution pre-made acrylamide-bisacrylamide solutions $(8 \% \mathrm{w} / \mathrm{v})$ were used, and the gels were run in $0.6 \mathrm{X}$ TBE buffer for 
$400 \min (1500 \mathrm{~V}, 60 \mathrm{~mA}, 25 \mathrm{~W})$ keeping the temperature constant at $50^{\circ} \mathrm{C}$.

The AFLP profiles and cluster analysis were elaborated by Quantity One ${ }^{\circledR}$ software (Bio-Rad) (www.bio-rad.com), using the Median algorithm as reported in the Quantity One user guide for version 4.2, Windows and Macintosh ${ }^{(}, 2000$ by Bio-Rad Laboratories (www.bio-rad.com), for the cluster analysis and dendrogram processing.

\section{Results and Discussion}

The accessions GA5, CH6 and LA4 diverged from the other twenty-two at four loci (VVS2, VVS4, VVMD7 and VVMD21). These accessions appear to be heterozygous at VVS2, VVS4 and VVMD7, and homozygous at VVMD21. The other twenty-two accessions, including positive controls for variety identification (B-BS-11, SS-F9-A5-48, Rauscedo 10), showed the opposite alleles at the same loci (Table 2). Interestingly, although divergent from "Sangiovese", the three accessions share one allele with the rest of the population. These results suggest that loci (VVMD3, VVS29, VVMD17, and VVMD6) did not show any polymorphism in the population considered and that the accessions tested are heterozygous at VVMD6 and VVMD17 and homozygous at VVMD3 and VVS29.

The allele sizes are reported in Table 2 and confirm the genetic identity of most presumed clones of "Sangiovese". Previous traditional ampelometric studies on the three divergent accessions already suggested that they were not really "Sangiovese" (Scalabrelli et al. 2001). The present findings support the hypothesis that GA5, CH6 and LA4 differ from the "Sangiovese" standard.

Athough the microsatellite amplification test is widely used to discriminate among quasi iso-genic populations and the use of DNA fingerprinting in many plant species has been widely criticized in the literature (McCouch et al. 1997; Glazko et al. 1998), the test does not seem to reliably distinguish registered clones (Sensi et al. 1996; Vignani et. al 1996).

In agreement with a strict definition of cultivar that poses the progeny as deriving from a single seedling (i.e. monoclonal origin) the three divergent accessions could not be included in "Sangiovese", but given the intrinsic limitation of the technique for clone identification, and if accepting polyclonal origin theory of cultivars (Scienza, 1993), it could be argued that they may simply be interpreted as "Sangiovese". However according to recent data (Sefc et al. 2000), the cumulative probabilities of obtaining identical genotypes from different cultivars ranges from $10^{-7}$ to $10^{-9}$, when the panel of microsatellites analysed shows enough heterozygosity $\left(\mathrm{H}_{\mathrm{e}}\right.$ 0,710-0,859). Since the variability observed in 51 different grape varieties
(Bowers, personal communication) for the microsatellite loci chosen is similar to internationally adopted variability for genetic characterization of European grapevines (Sefc et al. 2000), the molecular data support that the three divergent accessions, GA5, CH6 and LA4, showing a different allele configuration in $50 \%$ of the loci studied, have a different genetic identity to "Sangiovese".

AlleleLinks enables the researcher to process microsatellite data for each accession and to obtain pedigree analysis and genotype reports useful for variety identification. For genotyping, a specifically designed internal database for allele scoring of Vitis vinifera microsatellite amplified fragments was used.

An example of pre-linkage data and genotype report, for the probability evaluation of allelic configuration of each individual, is shown in Table 3. The data elaboration is based on the loci showing polymorphism in the Sangiovese-related family studied.

In order to obtain a more accurate and complete framework of the genomic identity of the divergent accessions, the AFLP test was also performed. AFLP techniques have been widely used for genotype description of plant species and to assess the degree of biodiversity within populations (Rouppe van der Voort et al. 1997; Breyne et al. 1999; Christopher and Donini, 1999), including V. vinifera (Sensi et al. 1996). More recently, AFLP testing using fluorescent dyes has been described as an alternative to radioactive labelling (Vrieling et al. 1997; Aarts et al. 1999; Herbergs et al. 1999; Lin et al. 1999). Although non-radioactive AFLP testing has already been described, to our knowledge, this is the first report of Cy ${ }^{\mathrm{TM}}$ 5-labelled AFLP of grapevines using an automated system. Furthermore, the use of Quantity One software (Bio-Rad) significantly simplified the evaluation of genetic similarity between accessions in the population studied, leading to various statistical options to obtain clusters. Figure 1 shows a digitalized electropherogram of an AFLP profile with Arabidopsis thaliana, Gingko biloba and Lycopersicon esculentum DNAs as negative controls. The blue arrows indicate several zones of polymorphism observed in GAL5, CH6 and LA4, confirming the results of microsatellite testing. Based on AFLP profiling, a phylogenetic diagram, can be used to group the population (Figure 2 into four main clusters, which distinguish individuals at species level: A, B, and C correspond to G. biloba, A. thaliana and $L$. esculentum respectively, while $\mathrm{D}$ includes all the $V$. vinifera accessions analysed. It is noteworthy that the divergent accessions CH6 and LA4 form a cluster and GA5 is not far from them but separate from the other "Sangiovese" accessions.

As already proposed elsewhere (Karp et al. 1997; Vignani et al. 1999) the results presented in this paper clearly show 
that modern biotechnological tools, especially DNA tests based on easy-to-handle PCR-based techniques, can make significant contribution in crop breeding research. For $V$. vinifera in particular, molecular diagnostic tools can detect cases of genetic divergence and erroneous variety assignment early in the long process of traditional clonal selection. These cases could otherwise lead to misnaming and waste of human and financial resources.

\section{Acknowledgements}

We wish to thank Prof. G. Scalabrelli from the University of Pisa and Prof. M. Boselli and his collaborator, Mr. R. Bandinelli for providing plant material.

\section{References}

AARTS, H.J.M.; HAKEMULDER, L.E. and VAN HOEF, A.M.A. Genomic typing of Lysteria monocytogenes strains by automated laser fluorescence analysis of amplyfied length polymorphism fingerprinting patterns. International Journal of Food and Microbiology, August 1999, vol. 49, no.1-2, p. 95-102.

BOWERS, John; BOURSIQUOT, Jean-Michel; THIS, Patrice; CHU, Kieu; JOHANSSON, Henrik and MEREDITH, Carole. Historical genetics: the parentage of Chardonnay, Gamay, and other wine grapes of northeastern France. Science, September 1999, vol. 285, no. 5433, p. 1562-1565.

BOWERS, John and MEREDITH, Carole P. The parentage of a classic wine grape, Cabernet Sauvignon. Nature Genetics, May 1997, vol. 16, no. 1, p. 84-87.

BOWERS, John; DANGL, Gerald Savage; VIGNANI, Rita and MEREDITH, Carole. Isolation and characterization of new polymorphic simple sequence repeat loci in grape (Vitis vinifera L.). Genome, August 1996, vol. 39, no. 4, p. 628-633.

BREYNE, P. ROMBAUT, D.; VAN GYSEL, A.; VAN MONTAGU, M. and GERATS, T. AFLP analysis of genetic diversity within and between Arabidopsis thaliana ecotypes. Molecular General Genetics, June 1999, vol. 26, no. 4-5, p. 627-634.

CHRISTOPHER, J.R. and DONINI, P. Use of AFLP in cereals research. Trends in Plant Science, February 1999, vol. 4, no. 2, p.76-79.

CIPRIANI, G.; FRAZZA, G.; PETERLUNGER, E. and TESTOLIN, R. Grapevine fingerprinting using microsatellite repeats. Vitis, December 1994, vol. 33, no. 4, p. 211-215.
DETTWEILER, E.; JUNG, A.; ZYPRIAN, E. and TÖPFER, R. Grapevine cultivar Müller-Thurgau and its true to type descent. Vitis, June 2000 , vol. 39 , no. 2, p. 6365 .

FREGONI, M. Ampelografia. In: FREGONI, M. ed. Viticoltura di qualità. Verona, Italy, L'Informatore Agrario S.r L., 1999, p. 49-160.

GLAZKO, V.I.; DOMANSKII, N.N. and SOZINOV, A.A. Current trends in the use of DNA technologies. TSitologiia i genetika, September-October 1998, vol. 32, no. 5, p. 8093.

HERBERGS, J.; SIWEK, M.; CROOIJMANS, R.P.M.A.; VAN DER POEL, J.J. and GROENEN, M.A.M. Multicolor fluorescent detection and mapping of AFLP markers in chicken (Gallus domesticus). Animal Genetics, August 1999, vol. 30, no.4, p. 274-285.

KARP, A.; EDWARDS, K.J.; BRUFORD, M.; FUNK, S.; VOSMAN, B.; MORGANTE, M.; SEBERG, O.; KREMER, A.; BOURSOT, P.; ARCTANDER, P.; TAUTZ, D. and HEWITT, G.M. Molecular technologies for biodiversity evaluation: opportunities and challenges. Nature Biotechnology, July 1997, vol. 15, no. 7, p. 625628.

LIN, J.J.; MA, J. and KUO, J. Chemioluminescent detection of AFLP markers. Biotechniques, February 1999, vol. 26 , no. 2 , p. $344-348$.

MCCOUCH, S.R.; CHEN, X.; PANAUD, O.; TEMNYKH, S.; XU, Y.; CHO, Y.G.; HUANG, N.; ISHII, T. and BLAIR, M. Microsatellite marker development, mapping and applications in rice genetics and breeding. Plant Molecular Biology, September 1997, vol. 35, no.1-2, p. 8999.

MORGANTE, M. and OLIVIERI, A.M. PCR-amplified microsatellites as markers in plant genetics. The Plant Journal, January 1993, vol. 3, no. 1, p. 175-182.

MULCAHY, David; CRESTI, Mauro; SANSAVINI, Silviero; DOUGLAS, Christopher; LINSKENS, Hans Ferdinand; BERGAMINI-MULCAHY, Gabriella; VIGNANI, Rita and PANCALDI, Marco. The use of random amplified polymorphic DNAs to fingerprint apple genotypes. Scientia Horticulturae, May 1993, vol. 54, no. 2, p. 89-96.

ROUPPE VAN DER VOORT, J.N.; VAN ZANDOVOORT, P.; VAN ECK, H.J.; FOLKERTMA, R.T.; HUTTEN, R.C.; DRAAISTRA, J.; GOMMERS, F.J.; JACOBSEN, E.; HELDER, J and BAKKER, I Use of allele specificity comigrating markers to align genetic maps 
from different potato genotypes. Molecular General Genetics, July 1997, vol. 255, no. 4, p. 438-447.

SCALABRELLI, Giancarlo; VIGNANI, Rita; SCALI, Monica; DI PIETRO, Donatella; MATERAZZI, Alberto and TRIOLO, Enrico. Il Morellino pizzuto: un biotipo di Sangiovese? In: "Il Sangiovese": Proceedings of the International Symposium Il Sangiovese (15th-17th February, 2000, Florence, Italy). "Il Sangiovese", Atti ARSIA, Agenzia Regionale per lo Sviluppo e l'Innovazione in Agricoltura della Regione Toscana, eds., Abstracts, 2001. p. 107.

SCIENZA, A. Vigneti policlonali e valorizzazione della diversità dei vini. Vignevini, December 1993, vol. 20, no. 12 , p. 23-24.

SEFC, K.M.; LOPES, M.S.; LEFORT, F.; BOTTA, R.; ROUBELAKIS-ANGELAKIS, K.A.; IBÁÑEZ, J.; PEJIÉ, I.; WAGNER, H.W.; GLÖSSL, J. and STEINKELLNER, H. Microsatellite variability in grapevine cultivars from different European regions and evaluation of assignment testing to assess the geographic origin of cultivars. Theoretical Applied Genetics, February 2000, vol.100, no. 3-4, p.498-505.

SEFC, K.M.; STEINKELLNER, H.; GLOSSL, J.; KAMPFER, S. and REGNER, F. Reconstruction of a grapevine Pedigree by microsatellite analysis. Theoretical Applied Genetics, July 1998, vol. 97, no.1-2, p. 227-231.

SENSI, Bisabetta; VIGNANI, Rita.; RHODE, Wolfgang and BIRICOLTI, Stefano. Characterization of genetic biodiversity with Vitis vinifera L. Sangiovese and Colorino genotypes by AFLP and ISTR marker technology. Vitis, December 1996, vol. 35, no.4, p. 183-188.

SILVESTRONI, Oriana; DI PIETRO, Donatella; INTRIERI, Cesare; VIGNANI, Rta; FILIPPETTI, llaria; DEL CASINO, Cecilia; SCALI, Monica and CRESTI, Mauro. Detection of genetic diversity among clones of cv. Fortana (Vitis vinifera L.) by microsatellite DNA polymorphism analysis. Vitis, September 1997, vol. 36, no. 3, p. 147-150.

THOMAS, M.R.; CAIN, P. and SCOTT, N.S. DNA typing of grapevines: a universal methodology and database for describing cultivars and evaluating genetic relatedness. Plant Molecular Biology, September 1994, vol. 25, no. 6, p. 939-949.

THOMAS, M.R. and SCOTT, N.S. Microsatellite repeats in grapevine reveal DNA polymorphism when analysed as sequence-tagged sites (STSs). Theoretical Applied Genetics, April 1993, vol. 86, no. 2-3, p.173-180.
VIGNANI, Rita; Scali, Monica and CRESTI, Mauro. Grapevine biotechnology coming on to the scene. In: CRESTI, M.; CAI, G. and MOSCATELLI, A., eds. Fertilization in higher plants. Springer Verlag, Berlin, Heidelberg, New York, 1999, p. 413-425.

VIGNANI, Rita; BOWERS, John and MEREDITH, Carole. Microsatellite DNA polymorphism analysis of clones of V. vinifera "Sangiovese". Scientia Horticulturae, June 1996, vol. 65 , no. 2-3, p. 163-169.

VOS, P.; HOGERS, R.; BLEEKER, M.; REIJANS, M.; VAN DE LEE, T.; HORNES, M.; FRIJTERS, A.; POT, J.; PELEMAN, J.; KUIPER, M. and ZABEAU, M. AFLP: A new technique for DNA fingerprinting. Nucleic Acid Research, November 1995, vol. 23, no. 21, p. 4407-4414.

VRIELING, K.; PETERS, J. and SANDBRINK, $\mathrm{H}$. Amplified Fragment Length Polymorphisms (AFLPs) detected with non-radiactive digoxigenine labelled primers in three plant species. Plant Molecular Biology Reporter, September 1997, vol. 15, no. 3, p. 255-262. 


\section{APPENDIX}

Tables

Table 1. List of registered clones and presumed clones of "Sangiovese".

\begin{tabular}{|c|c|}
\hline $\begin{array}{c}\text { Genotype origin in } \\
\text { Tuscany } \\
\end{array}$ & Individual \\
\hline \multirow{15}{*}{ Scansano (Grosseto) } & GA2 \\
\hline & GA5 \\
\hline & GA10 \\
\hline & GA12 \\
\hline & GA15 \\
\hline & GA16 \\
\hline & GA17 \\
\hline & $\mathrm{CH} 1$ \\
\hline & $\mathrm{CH} 5$ \\
\hline & $\mathrm{CH} 6$ \\
\hline & $\mathrm{CH} 8$ \\
\hline & $\mathrm{CH} 10$ \\
\hline & $\mathrm{CH} 12$ \\
\hline & LA4 \\
\hline & ROSSI3 \\
\hline \multirow{5}{*}{ Val di Cornia (Livorno) } & COR5 \\
\hline & COR14 \\
\hline & COR20 \\
\hline & COR33 \\
\hline & COR35 \\
\hline \multirow{2}{*}{ Montalcino (Siena) } & BD1 \\
\hline & $\mathrm{BD} 2$ \\
\hline \multirow{3}{*}{$\begin{array}{l}\text { Germoplasm collection, } \\
\text { University of Florence }\end{array}$} & SS-F9-A5-48 \\
\hline & B-BS-11 \\
\hline & RAUSCEDO 10 \\
\hline
\end{tabular}


Table 2. DNA fragment sizes (in bp) amplified with eight microsatellite markers in twenty-five accessions. The table includes registered clones of "Sangiovese" (in red). The three divergent accessions are indicated in bold.

\begin{tabular}{|c|c|c|c|c|c|c|c|c|}
\hline Individual & VVS2 & VVS4 & VVS29 & VVMD3 & VVMD6 & VVMD7 & VVMD17 & VVMD21 \\
\hline GA2 & 132,132 & 160,168 & 170,170 & 280,280 & 194,214 & 239,263 & 212,221 & 244,250 \\
\hline GA5 & 132,153 & 168,175 & 170,170 & 280,280 & 194,214 & 239,250 & 212,221 & 250,250 \\
\hline GA10 & 132,132 & 160,168 & 170,170 & 280,280 & 194,214 & 239,263 & 212,221 & 244,250 \\
\hline GA12 & 132,132 & 160,168 & 170,170 & 280,280 & 194,214 & 239,263 & 212,221 & 244,250 \\
\hline GA15 & 132,132 & 160,168 & 170,170 & 280,280 & 194,214 & 239,263 & 212,221 & 244,250 \\
\hline GA16 & 132,132 & 160,168 & 170,170 & 280,280 & 194,214 & 239,263 & 212,221 & 244,250 \\
\hline GA17 & 132,132 & 160,168 & 170,170 & 280,280 & 194,214 & 239,263 & 212,221 & 244,250 \\
\hline $\mathrm{CH} 1$ & 132,132 & 160,168 & 170,170 & 280,280 & 194,214 & 239,263 & 212,221 & 244,250 \\
\hline CH5 & 132,132 & 160,168 & 170,170 & 280,280 & 194,214 & 239,263 & 212,221 & 244,250 \\
\hline CH6 & 132,153 & 168,175 & 170,170 & 280,280 & 194,214 & 239,250 & 212,221 & 250,250 \\
\hline $\mathrm{CH} 8$ & 132,132 & 160,168 & 170,170 & 280,280 & 194,214 & 239,263 & 212,221 & 244,250 \\
\hline $\mathrm{CH} 10$ & 132,132 & 160,168 & 170,170 & 280,280 & 194,214 & 239,263 & 212,221 & 244,250 \\
\hline CH12 & 132,132 & 160,168 & 170,170 & 280,280 & 194,214 & 239,263 & 212,221 & 244,250 \\
\hline COR5 & 132,132 & 160,168 & 170,170 & 280,280 & 194,214 & 239,263 & 212,221 & 244,250 \\
\hline COR14 & 132,132 & 160,168 & 170,170 & 280,280 & 194,214 & 239,263 & 212,221 & 244,250 \\
\hline COR20 & 132,132 & 160,168 & 170,170 & 280,280 & 194,214 & 239,263 & 212,221 & 244,250 \\
\hline COR33 & 132,132 & 160,168 & 170,170 & 280,280 & 194,214 & 239,263 & 212,221 & 244,250 \\
\hline COR35 & 132,132 & 160,168 & 170,170 & 280,280 & 194,214 & 239,263 & 212,221 & 244,250 \\
\hline LA4 & 132,153 & 168,175 & 170,170 & 280,280 & 194,214 & 239,250 & 212,221 & 250,250 \\
\hline ROSSI3 & 132,132 & 160,168 & 170,170 & 280,280 & 194,214 & 239,263 & 212,221 & 244,250 \\
\hline BD1 & 132,132 & 160,168 & 170,170 & 280,280 & 194,214 & 239,263 & 212,221 & 244,250 \\
\hline BD2 & 132,132 & 160,168 & 170,170 & 280,280 & 194,214 & 239,263 & 212,221 & 244,250 \\
\hline SS-F9-A5-48 & 132,132 & 160,168 & 170,170 & 280,280 & 194,214 & 239,263 & 212,221 & 244,250 \\
\hline B-BS-11 & 132,132 & 160,168 & 170,170 & 280,280 & 194,214 & 239,263 & 212,221 & 244,250 \\
\hline RAUSCEDO 10 & 132,132 & 160,168 & 170,170 & 280,280 & 194,214 & 239,263 & 212,221 & 244,250 \\
\hline
\end{tabular}


Table 3. The "Sangiovese" genotype report obtained after AlleleLinks elaboration observed at the loci (VVS2, VVS4, VVMD7 and VVMD21). This report showed polymorphism for GA5, CH6 and LA 4. The allele configuration for each accession at the above four loci derived from pre-linkage data refer to an internal database ${ }^{1}$. Genotype information is deduced from the most probable allelic configuration determined by the software which resolves multiple possible genotypes, evaluating of the probability value assigned to paternal and maternal allele, after removing impossible alleles (not present in either parent).

\begin{tabular}{lllll}
\hline \hline Individual & VVS2 & VVS4 & VVM7 & VVM21 \\
\hline \hline GA2 & 1 & 2,4 & $2,6+$ & 1,2 \\
\hline GA5 & $\mathbf{1 , 1 0}$ & $\mathbf{4 , 5}$ & $\mathbf{2 , 4 +}$ & $\mathbf{2}$ \\
\hline GA10 & 1 & $2,4+$ & $2,6+$ & 1,2 \\
\hline GA12 & 1 & 2,4 & $2,6+$ & 1,2 \\
\hline GA15 & 1 & $2,4+$ & $2,6+$ & 1,2 \\
\hline GA16 & 1 & 2,4 & $2,6+$ & 1,2 \\
\hline GA17 & 1 & 2,4 & $2,6+$ & 1,2 \\
\hline CH1 & 1 & 2,4 & $2,6+$ & 1,2 \\
\hline CH5 & 1 & 2,4 & $2,6+$ & 1,2 \\
\hline CH6 & $\mathbf{1 , 1 0}$ & $\mathbf{4 , 5}$ & $\mathbf{2 , 4 +}$ & $\mathbf{2}$ \\
\hline CH8 & 1 & 2,4 & $2,6+$ & 1,2 \\
\hline CH10 & 1 & $2,4+$ & $2,6+$ & 1,2 \\
\hline CHI2 & 1 & $2,4+$ & $2,6+$ & 1,2 \\
\hline COR5 & 1 & 2,4 & $2,6+$ & 1,2 \\
\hline COR14 & 1 & 2,4 & $2,6+$ & 1,2 \\
\hline COR20 & 1 & 2,4 & $2,6+$ & 1,2 \\
\hline COR33 & 1 & 2,4 & $2,6+$ & 1,2 \\
\hline COR35 & 1 & 2,4 & $2,6+$ & 1,2 \\
\hline LA4 & $\mathbf{1 , 1 0}$ & $\mathbf{4 , 5}$ & $\mathbf{2 , 4 +}$ & $\mathbf{2}$ \\
\hline ROSSI3 & 1 & 2,4 & $2,6+$ & 1,2 \\
\hline BD1 & 1 & 2,4 & $2,6+$ & 1,2 \\
\hline BD2 & 1 & 2,4 & $2,6+$ & 1,2 \\
\hline SS-F9-A548 & 1 & 2,4 & $2,6+$ & 1,2 \\
\hline B-BS-11 & 1 & 2,4 & $2,6+$ & 1,2 \\
\hline RAUSCEDO10 & 1 & 2,4 & $2,6+$ & 1,2 \\
\hline \hline & & & & \\
\hline
\end{tabular}

\footnotetext{
${ }^{1}$ In the internal data base possible alleles (observed) for $V$. Vinifera are arbitrarily assigned progressive numbers as follows: VVS2 $1=132,2=135,3=137,4=139,5=143,6=145 ; 7=147 ; 8=149 ; 9=151 ; 10=153 ; 11=155$

VVS4 $1=156 ; 2=160 ; 3=166 ; 4=168 ; 5=175$

VVMD7 1=233; 2=239; 3=240; 4=250; $5=253 ; 6=263 ; 7=265$

VVMD21 $1=244 ; 2=250 ; 3=254 ; 4=256 ; 5=258 ; 6=266$

+ presence of scored alleles with lower probability
} 


\section{Figures}

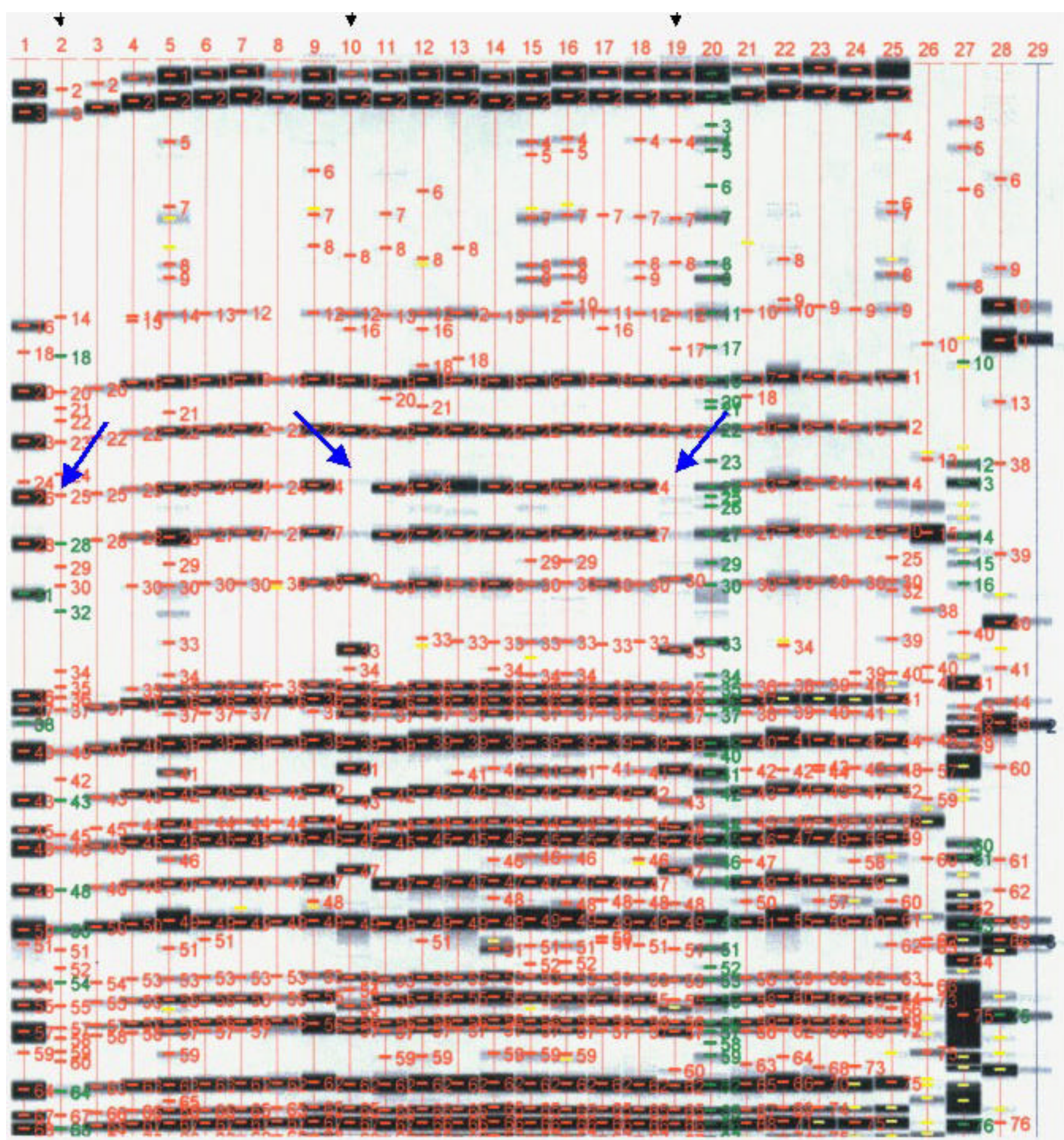

Known band type - Matched bands - Standards -

Figure 1. A digitalized electropherogram of the AFLP profiles obtained for the 25 accessions analysed The order of lanes from left to right follows the order of accessions listed in Table 1. Lane 26 Gingko biloba. Lane 27 Lycopersicon esculentum. Lane 28 Arabidopsis thaliana. Lane 29 standards (50,100 and $250 \mathrm{bp}$ ). The colour codes used for labelling the bands in the picture are: green indicating a known band type (i.e. bands which identify standards); red indicating bands matched with respect to standards; yellow indicating unclassified bands (i.e. bands which cannot be matched to standards); blue arrows indicate a polymorphism zone in divergent accessions with respect to the "Sangiovese" clones. 


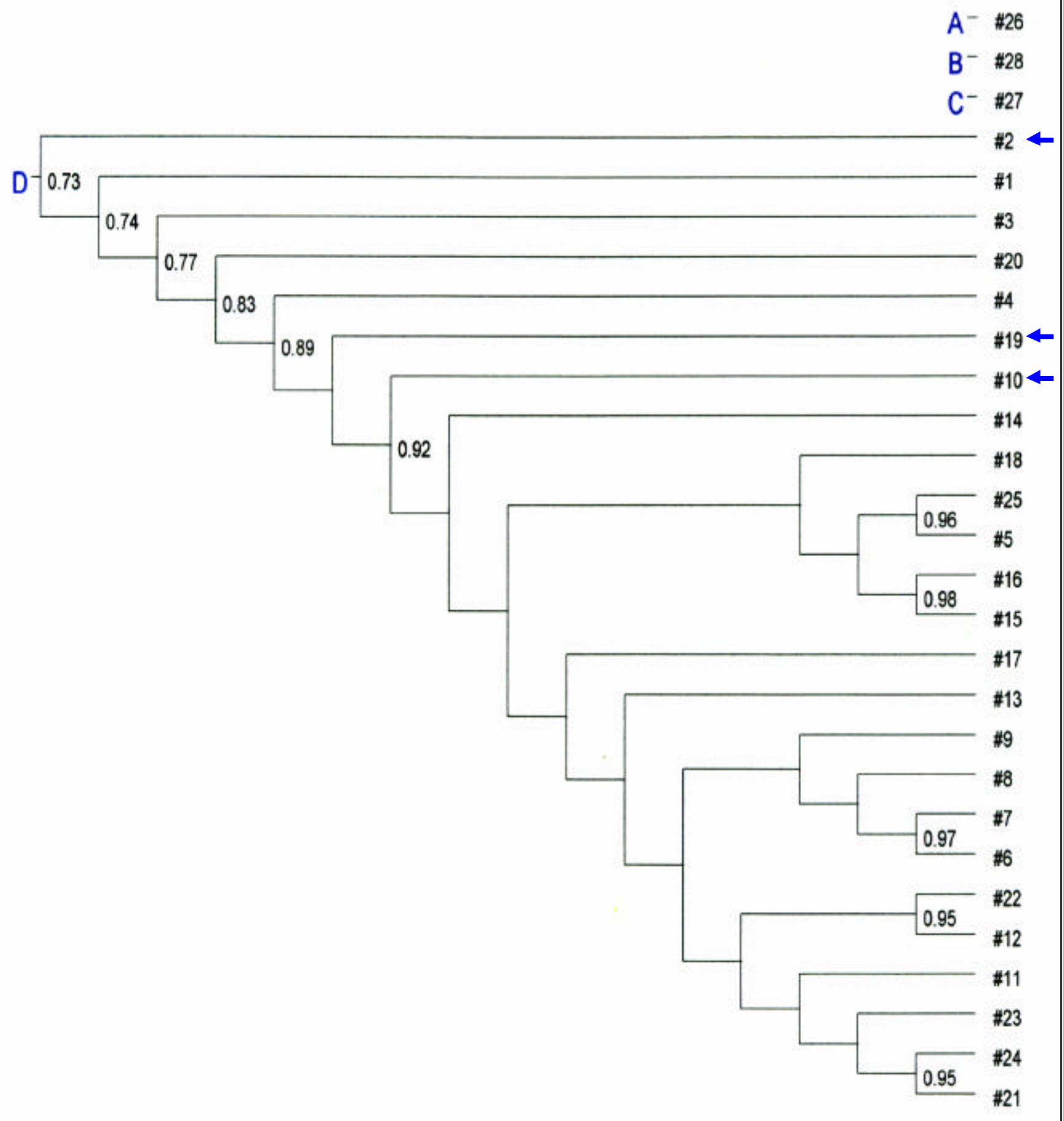

Figure 2. Cluster analysis of Vitis vinifera accessions studied based on the AFLP profiling and Quantity One processing. The numbers from 1 to 29 in the dendrogram correspond to the AFLP electropherogram lanes in Figure 1. Arrows indicate the divergent accessions. 